\title{
Application of Remote Sensing for Impacts Assessment of Petroleum Activities and Facilities in Bongor Basin, Chad Republic
}

\author{
Samba Koukouare Prosper ${ }^{1,2}$, Dorim Ngarbaroum ${ }^{1,2}$, Ewodo Mboudou Guillaume ${ }^{2}$, \\ Djim-Assal Datoloum ${ }^{3}$, Danwe Raindandi ${ }^{2}$ \\ ${ }^{1}$ Department of Hydrocarbons Exploitation, Higher National Institute of Petroleum of Mao, Mao, Chad \\ ${ }^{2}$ National Higher School of Engineering of Maroua, University of Maroua, Maroua, Cameroon \\ ${ }^{3}$ National Research Center for Development (CNRD), Ministry of Higer Education, N'Djamena, Chad
}

Email address:

sakoupros@gmail.com (S. K. Prosper)

\section{To cite this article:}

Samba Koukouare Prosper, Dorim Ngarbaroum, Ewodo Mboudou Guillaume, Djim-Assal Datoloum, Danwe Raindandi. Application of Remote Sensing for Impacts Assessment of Petroleum Activities and Facilities in Bongor Basin, Chad Republic. American Journal of Environmental Protection. Vol. 9, No. 4, 2020, pp. 86-96. doi: 10.11648/j.ajep.20200904.12

Received: August 14, 2020; Accepted: August 26, 2020; Published: September 3, 2020

\begin{abstract}
The objective of this study is to compare various changes of ecological parameters within time period prior petroleum activities and after facilities establishment in Bongor basin. Analysis of landsat 7 images from March 24 to April 5, 2000 and that of landsat 8 from February 13, 2015, before and after oil operations respectively, made it possible to extract four biophysical indices, namely: brightness index of soil, moisture index, greenness index and vegetation index. Maps of land use, hydrology and pedology were established from the analysis of multispectral parameters variations. Significant variations between two study periods were then evaluated to be either increasing, declining or stable over the entire Bongor basin and in the areas of the basin under operations. It appears that, shrub savanna has declined by $15.75 \%$ over the entire Bongor basin and by $18.90 \%$ in the areas of oil operations in Bongor basin. Floodplain and the water body have also declined by $1.59 \%$ and $0.0007 \%$ respectively over the whole Bongor basin and loss of paddy field. Agricultural area has increased by $15.15 \%$ in Bongor basin and by $14.40 \%$ in the operations area of Bongor basin, with industrial area occupying $4.49 \%$ and the expansion of urbanized area of $0.01 \%$. Silting up of flood zone over the entire Bongor basin has increased by $0.35 \%$. Areas under oil operations, illustrate impacts of activities on soil, trees and groundwater.
\end{abstract}

Keywords: Oil Facilities, Impacts, Basin, Bongor, Chad

\section{Introduction}

Remote sensing is a reliable tool for monitoring various changes in land cover using satellite data. Studies on land use and land cover changes attempt to explain, where changes in environment are occurring, what types of land cover are changing, what types of transformation are occurring, at which rates land cover has changed, what are the driving forces and the immediate causes of these changes [17]. Landsat spectral data represent real physical properties and useful environmental covariates that can be derived for vegetation, soil and material, and their quantitative relationships used to predict soil and land distribution [6]. These remote sensing data are important component of land and soil mapping prediction. They provide spatial contiguous quantitative measure of surface reflectance, which is related to certain soil properties [10]. Assessment of petroleum activities and facilities damages on groundwater and the environment through the application of remote sensing, is considered an interesting method [16]. This tool facilitates mapping of inaccessible areas by reducing costly field surveys; it is true especially when acquiring data in arid and semi-arid areas where vegetation cover varies and mineralogical properties of soil surface and /or parental material are not completely covered by vegetation [11]. This aspect of research consists of acquiring and processing data and satellite images for the production of land use maps before and after oil exploitation. The objective of this work is to make a comparative study of 
ecological parameters during period before oil exploitation (year 2000) and period when oil activities were intensified (year 2015) in order to observe different changes associated with petroleum activities and facilities. On the basis of preliminary surveys, coupled with information from literature reviews, data processing and satellite images, the identification and evaluation of possible impacts of petroleum activities and facilities on environment and specifically on aquifer formations were carried out in this study.

\section{Materials and Methods}

\subsection{Study Area Presentation}

Bongor Basin is located between longitude $15.15^{\circ}$ and $17.50^{\circ} \mathrm{E}$ and between latitude $9^{\circ}$ and $11.25^{\circ} \mathrm{N}$ covering approximately $105,767 \mathrm{~km}^{2}$ [2]. It is spread over three regions namely, Chari Baguirmi region, Mayo Kebbi-Est region and Tandjilé region [2]. It is located south-east of Lake Chad, and the capital N'Djamena (Figure 1). Bongor basin is a flat region (province), a transitional zone between sahelian climate and sudanese climate $[24,5]$. Vegetation in this region is sudanese shrub savanna supported by sandy textured soils [3]. Forest stands are more or less dense to combretaceous; there are also open forests, shrub savanna, fallow land, meadows and gallery forests that border temporary water streams [3]. Fauna is generally found in area with little human occupation. Prosopis and Baobab areas have terrestrial fauna and are very rich of diverse avian [4]. Populations found in the region are farmers, sedentary and nomad breeders. Economically, subsistence farming is the main source of income, fishing and harvesting of non-timber forest products are secondary to household economic activities [24]. Main food crops grown are: penicillary millet, sorghum, pea nots, cowpeas, sesame, okra and sorrel [24].

\subsection{Methodology}

\subsubsection{Data Acquisition}

\section{(i) Mapping Data}

Land or soil base maps (Laï Sheet NC-33-11, Bongor Leaf NC-33-16) from ORSTOM 1968 and vegetation of Chad (Bousso Sheet NC-33-17) from ORSTOM 1968 served as reference maps for the production of the study area base maps using Arcgis 10.7 software.

\section{(ii) Field Data}

Perimeters limits of oil exploration and installations have been covered to identify and obtain with a GARMIN GPSMAP 64 GPS, reference points of main access roads to oil installations, various water points and habitations. Socioeconomic and environmental investigation of people in Bongor basin and those in areas close to oil facilities, have made it possible to make observations and obtain essential information for sound interpretation of remote sensing data.

\section{(iii) Spatial Data}

Collection of Landsat-7 satellite images from the periods of March 24 to April 05, 2000 (71830532000045edc00.tif, 71840522000324edc00.tif, 71840532000036edc00.tif and 71830542000045 edc00.tif) and Landsat-8 from February 13, 2015

(LC71800G54N18GLN00.tif,

LC81810462015282LGN00.tif and LC81810472015282LGN00.tif) covering oil zone from Koudalwa to Bongor, obtained freely from their owner on Earth Explorer, available on United States Geological Survey (http://earthexplorer.usgs.gov) website, were used for land use maps production. These data were provided in orthorectified form of the Universal Transverse Mercator (UTM) with the World Geodesic System (WGS) 1984 datum in Zone 33 of the Northern Hemisphere expressed as reflectance at the top of the atmosphere.

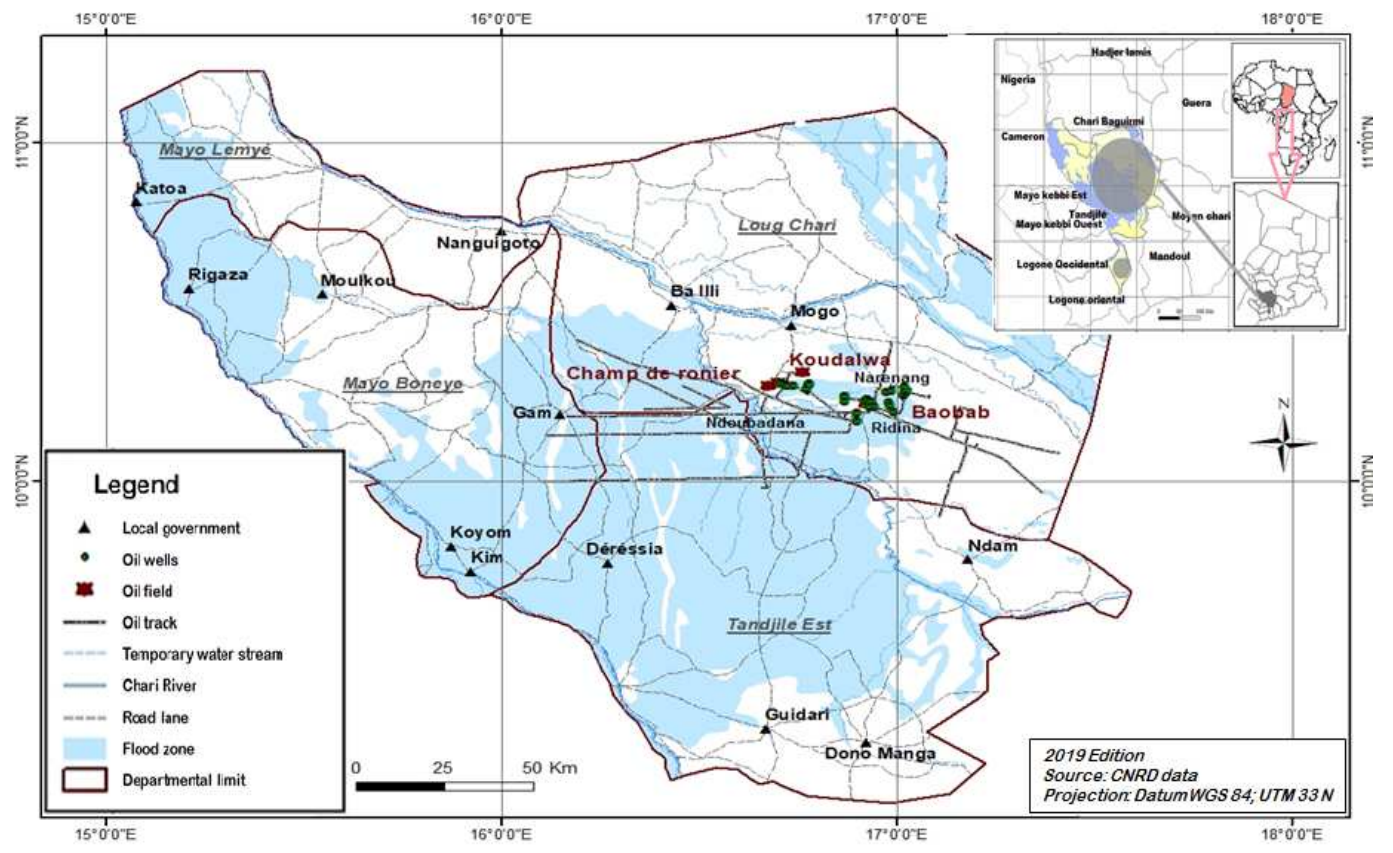

Figure 1. Map of the Bongor basin interfering with oil facilities. 


\subsubsection{Information Processing and Segmentation of Area Under Study}

Biophysical indices allow better discrimination of land use classes and reduce confusion [28]. Satellite images obtained were processed using ENVI software by color composition analysis. Then a filtration from the Spatial Analysis Tools (Majority filter) with a window size of $8 \times 8$ pixels was performed. The resulting interpretations made it possible to obtain four types of biophysical indices, namely: Brightness Index (BI), Wetness Index (NDWI), Greenness Index (GI) and Normalized Difference Vegetation Index (NDVI). The supervised classification process has enable visual interpretation of the different classes and assign them a name (vegetation, flood zone, wooded savanna) and generate descriptive statistics on the areas of different types of land use, for each of the two dates from 2000 and 2015. These data from the segmentation are exported under ArcGIS software for land use maps production. In order to be able to compare results between two periods 2000 and 2015, a nomenclature common to each class and compatible with the discrimination capacities of each was made. This nomenclature was based on threshold values of Reflectance channels of the near infrared (NIR), red, green blue, spatial information and vegetation index [9]. Colored compositions performed were intended to allow good discrimination of land use units and were obtained after orderly assignments to three primary colors.

\subsubsection{Assessment of Dynamic Land Use}

Different forms of conversion of land use units between two dates (2000) and (2015), and the description of possible changes were highlighted from transition matrix (SCHLAEPFER, 2002). The ArcGIS 10.7 Analysis Tools module has helped in obtaining spatial mutations of the classes during the two time intervals; the intersection is made between land occupations from ArcTool_AnalysisTools_Overlay_Intersect. Changes are obtained by crossing the land cover maps of 2000 and 2015 using Arc Toolbox_Analysis algorithm and the Tools_Intersect section under ArcGIS 10.7. The study area extraction was obtained from multispectral images with Basic Tools under ENVI. Images obtained were geometrically corrected based on the UTM33N Datum WGS84 projection.

\subsubsection{Land Cover Rate of Evolution}

The rate of change in space is obtained by calculating rates of change which are the annual rate of change and the overall or global rate of change of areas of land use classes between year 2000 and 2015. These rates of evolution are determined respectively by equations proposed by FAO (1996) and that of BERNIER (1992) cited mostly by researchers [19, 23]. It is expressed mathematically by the following relations:

FAO (1996)

$$
\operatorname{Tg}=\frac{\mathrm{S} 2-\mathrm{S} 1}{\mathrm{~S} 1} * 100
$$

With Tg: global rate of change; s1: area of a unit area class at date $\mathrm{t} 1$ and $\mathrm{s} 2$ the area of the same unit area class at date $\mathrm{t} 2$.

And Bernier (1992)

$$
\mathrm{Tc}=\frac{\ln S 2-\ln S 1}{(\mathrm{t} 2-\mathrm{t} 1) * \ln \mathrm{e}} * 100
$$

Where Tc: average annual rate of spatial expansion; s1: area of a unit area class at date $\mathrm{t} 1$ and $\mathrm{s} 2$ the area of the same unit area class at date $\mathrm{t} 2$; In natural logarithm; e base of the natural logarithm $(\mathrm{e}=2.71828)$.

\section{Results}

\subsection{Land Use in the Bongor Basin Year 2000}

Reference land use map, year 2000 (Figure 2), shows that savannas in general and agricultural areas occupy respectively more than $70 \%$ and $25.47 \%$ of the area in Bongor basin. Floodplain and paddy field are poorly and very poorly represented. Water body are almost in trace. Statistical analysis of the areas represented by these entities in the Bongor basin (Table 1) shows that shrub savanna represents $69 \%(2,694,085.25$ ha) of the total area of the basin. The agricultural zone is $25.47 \%(992,837.60 \mathrm{ha})$. Floodplain covers $198,255.42$ ha which is $5.09 \%$ of the total area. Herbaceous savanna covers 6380.68 ha representing $0.16 \%$ of area and wooded savanna is $0.10 \%$ (3724.75 ha) of the area. Paddy field and water body have very small areas with 2923.07 ha and 198.12 ha or $0.07 \%$ and $0.01 \%$ respectively.

Table 1. Ecological parameters of the Bongor basin before oil exploitation (year 2000).

\begin{tabular}{lll}
\hline Landscape year 2000 & Area (ha) & Percentage \\
\hline Agricultural area & $992,837.60$ & $25.47 \%$ \\
Water body & 198.12 & $0.01 \%$ \\
Herbaceous savanna & $6,380.68$ & $0.16 \%$ \\
Wooded savanna & $3,724.75$ & $0.10 \%$ \\
Shrub savanna & $2,694,085.25$ & $69 \%$ \\
Paddy field & $2,923.07$ & $0.07 \%$ \\
Floodplain & $198,255.42$ & $5.09 \%$ \\
Industrial zone & & \\
Total & $3,898,404.88$ & $100.00 \%$ \\
\hline
\end{tabular}

\subsection{Land Use in the Bongor Basin Year 2015}

Illustration of land use (year 2015) by oil facilities as well as the road network in place in Bongor basin is shown in Figure 3. The establishment of oil facilities in the area brings about significant change to vegetation, agricultural area, flood zone, paddy field and the water body. Within this period, savannas occupy $55.44 \%$ of the total area of the basin: the shrub savanna represents $53.25 \%$ $(2,075,923.07 \mathrm{ha})$ of total area; herbaceous savanna occupies $78,759.42$ ha $(2.02 \% \%)$ and wooded savanna is $6,785.35$ ha or $0.17 \%$. Agricultural zone occupies $40.62 \%$ of area making $1,583,538.61$ ha and floodplain area is $136,523.76$ ha, or $3.50 \%$. We also observe industrial zone 
establishment occupying $0.08 \%$ of the basin. The drying up of streams that are isolated from their sources, give way to silting up of the area with sand occupying $13,628.32$ ha or $0.35 \%$, and water body with a very small area of 118,62 ha or $0.003 \%$.

Table 2. Ecological parameters of the Bongor basin with oil activities (year 2015).

\begin{tabular}{lll}
\hline 2015 Landscape of Bongor & Area (ha) & Percentage \\
\hline Agricultural zone & $1,583,538.61$ & $40.62 \%$ \\
Water body & 118.62 & $0.003043 \%$ \\
Herbaceous savanna & $78,759.42$ & $2.02 \%$ \\
Wooded savanna & $6,785.35$ & $0.17 \%$ \\
Shrub savanna & $2,075,923.07$ & $53.25 \%$ \\
Sand & $13,628.32$ & $0.35 \%$ \\
Floodplain & $136,523.76$ & $3.50 \%$ \\
Industrial zone & $3,127.45$ & $0.08 \%$ \\
Total & $3,898,404.88$ & $100.00 \%$ \\
\hline
\end{tabular}

\subsection{Occupation of Space in Oil Zone of Influence and Exploitation in 2000 Before the Activity}

The intensified zone of operations in year 2000 before petroleum activities (Figure 4), represents KOUDALWA oil zone over a radius of 75 kilometers. Agricultural zone in this area occupies 44,023 ha, or $2.49 \%$; a shrub to wooded savanna covers $1,722,538$ ha, which is $97.47 \%$ of the total area; industrial zone and an urbanized zone occupy respectively 125 ha and 109 ha, representing $0.01 \%$ each (Table 3). Water body and floodplain have 168 ha and 208 ha respectively with each parameter representing $0.01 \%$ (Table 3).
Table 3. Ecological parameters in the oil operations zone (year 2000).

\begin{tabular}{lll}
\hline Landscape year 2000 & Area (ha) & Percentage \\
\hline Agricultural zone & 44,023 & $2.49 \%$ \\
Shrub to wooded savanna & $1,722,538$ & $97.47 \%$ \\
Industrial zone & 125 & $0.01 \%$ \\
Water body & 168 & $0.01 \%$ \\
Floodplain & 208 & $0.01 \%$ \\
Urbanized area & 109 & $0.01 \%$ \\
Total & $1,767,170$ & $100.00 \%$ \\
\hline
\end{tabular}

\subsection{Occupation of Space in the Zone of Influence of Oil Exploitation During Activity in 2015}

Oil exploitation zone in KOUDALWA (Figure 5), shows oil facilities and road networks. Statistical descriptions of ecological parameters in 2015 (Table 4) show a change in land use with an agricultural area covering 298,524 ha or $16.89 \%$; a shrub-to-wooded savanna with a surface area of 388,537 ha or $78.57 \%$; an industrial zone covers 79,453 ha or $4.50 \%$; water body and floodplain are extended to 157 ha and 184 ha respectively. The urbanized area occupies 315 ha $(0.02 \%)$ of the Bongor oil exploitation zone.

Table 4. Ecological parameters in oil operation zone (year 2015).

\begin{tabular}{lll}
\hline Landscape year 2000 & Area (ha) & Percentage \\
\hline Agricultural zone & 298,524 & $16.89 \%$ \\
Shrub to wooded savanna & $1,388,537$ & $78.57 \%$ \\
Industrial zone & 79,453 & $4.50 \%$ \\
Water body & 157 & $0.01 \%$ \\
Floodplain & 184 & $0.01 \%$ \\
Urbanized area & 315 & $0.02 \%$ \\
Total & $1,767,170$ & $100.00 \%$ \\
\hline
\end{tabular}

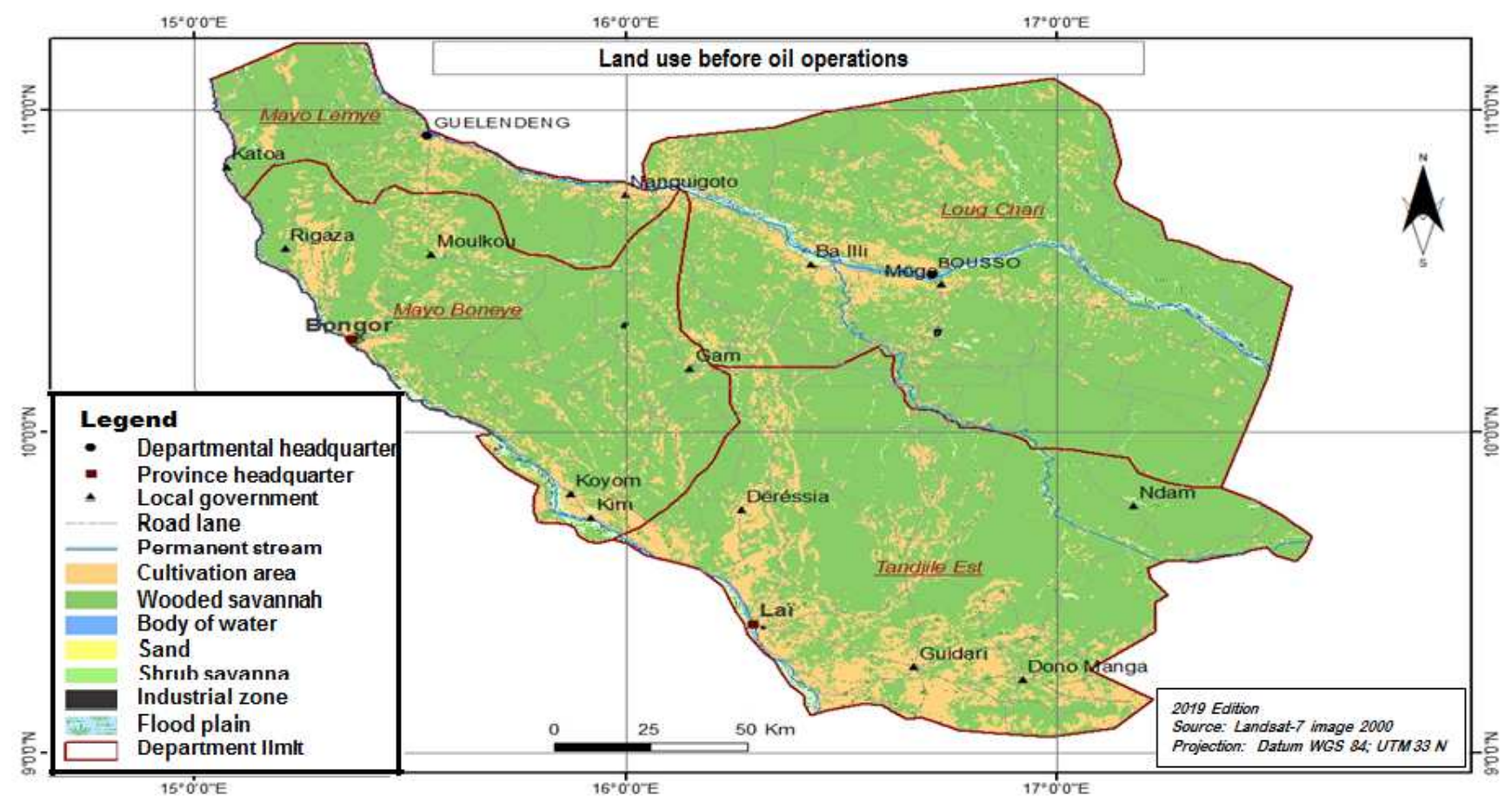

Figure 2. Bongor basin in year 2000, prior to complex establishment of oil facilities: flood and paddy fields are visible, vegetation is appreciable and agricultural areas are minimal. 


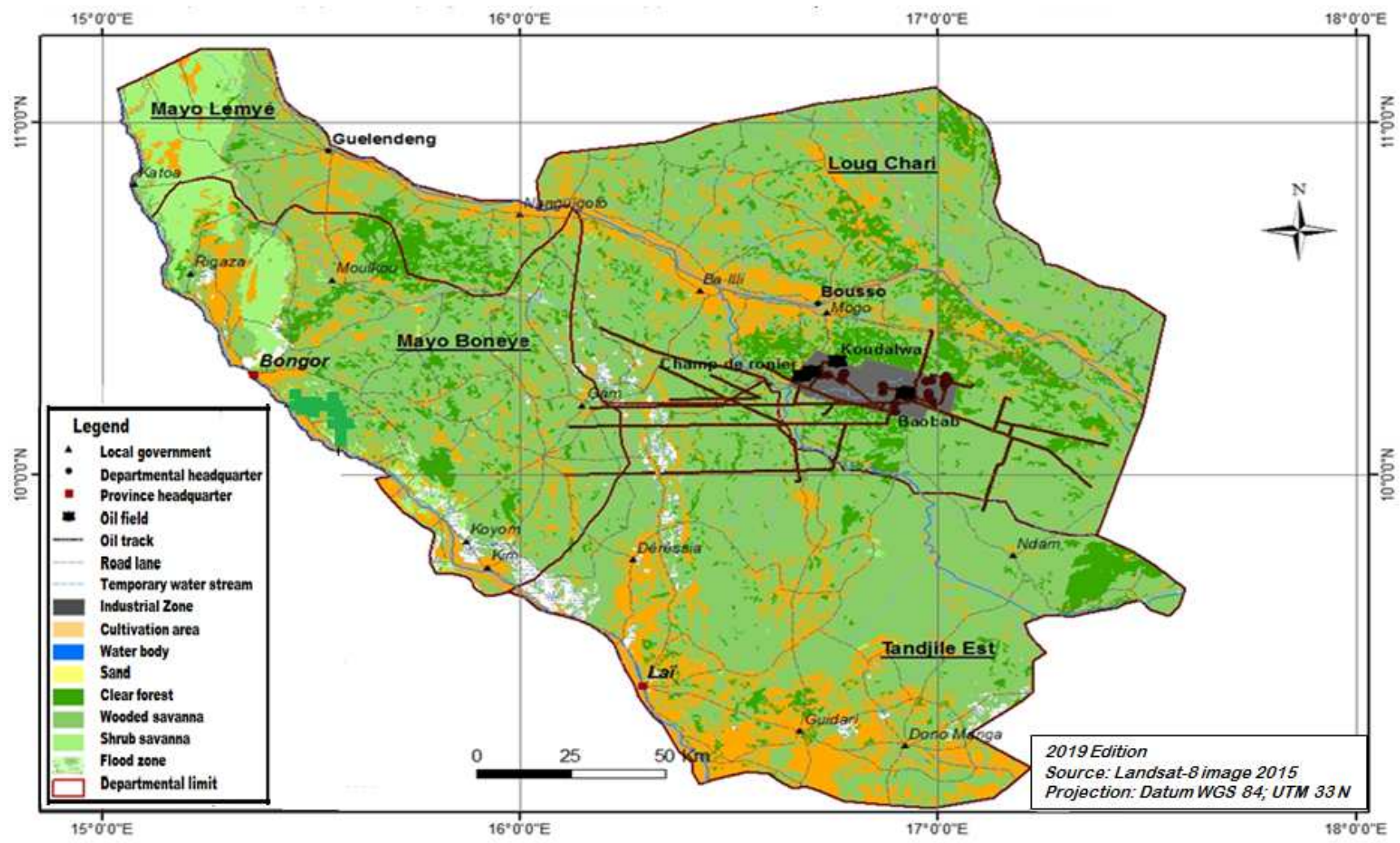

Figure 3. Bongor basin (globally) in year 2015; illustrating oil facilities as well as road networks.

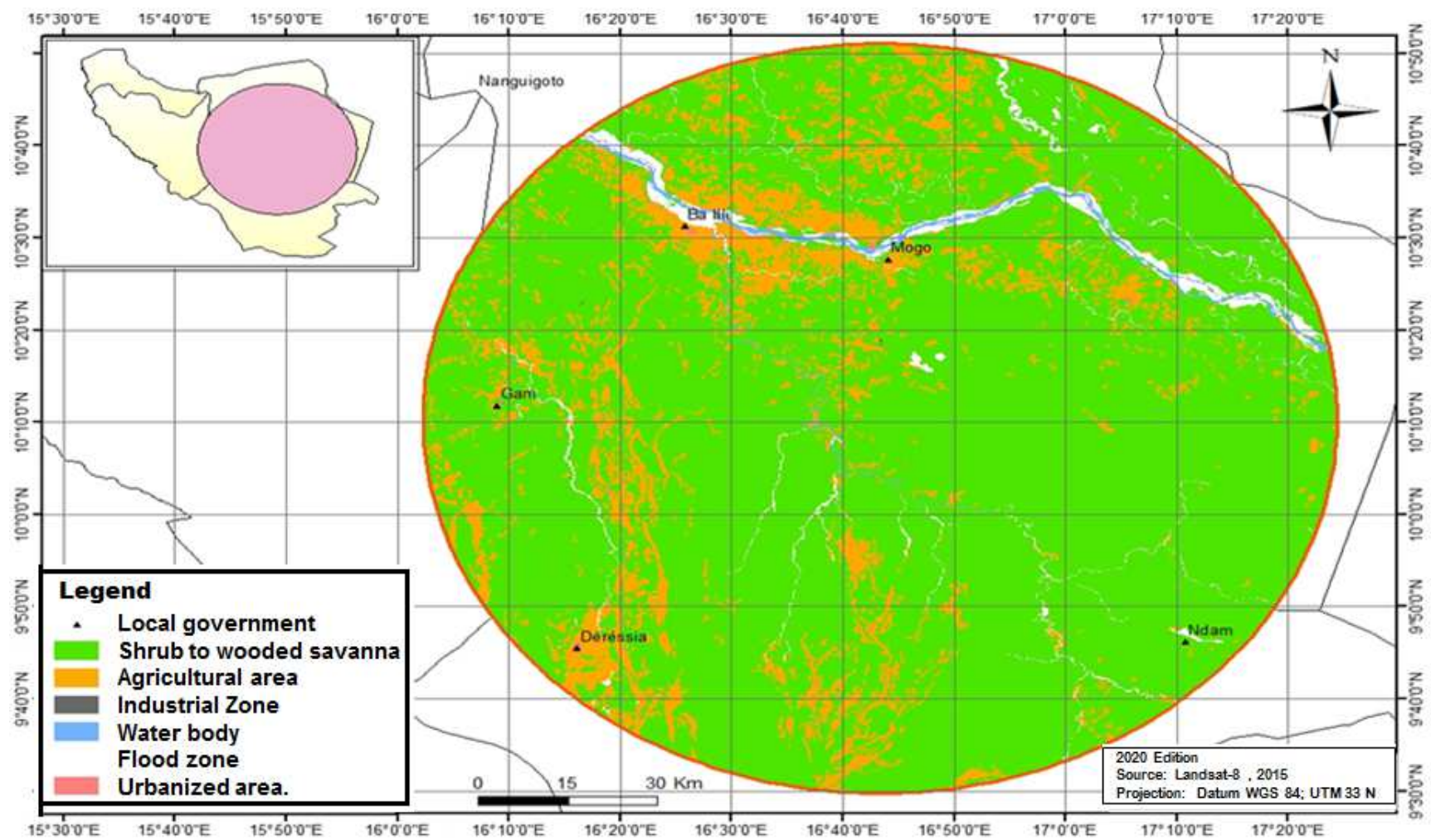

Figure 4. Bongor basin oil zone in year 2000, prior to complex oil facilities establishment. 


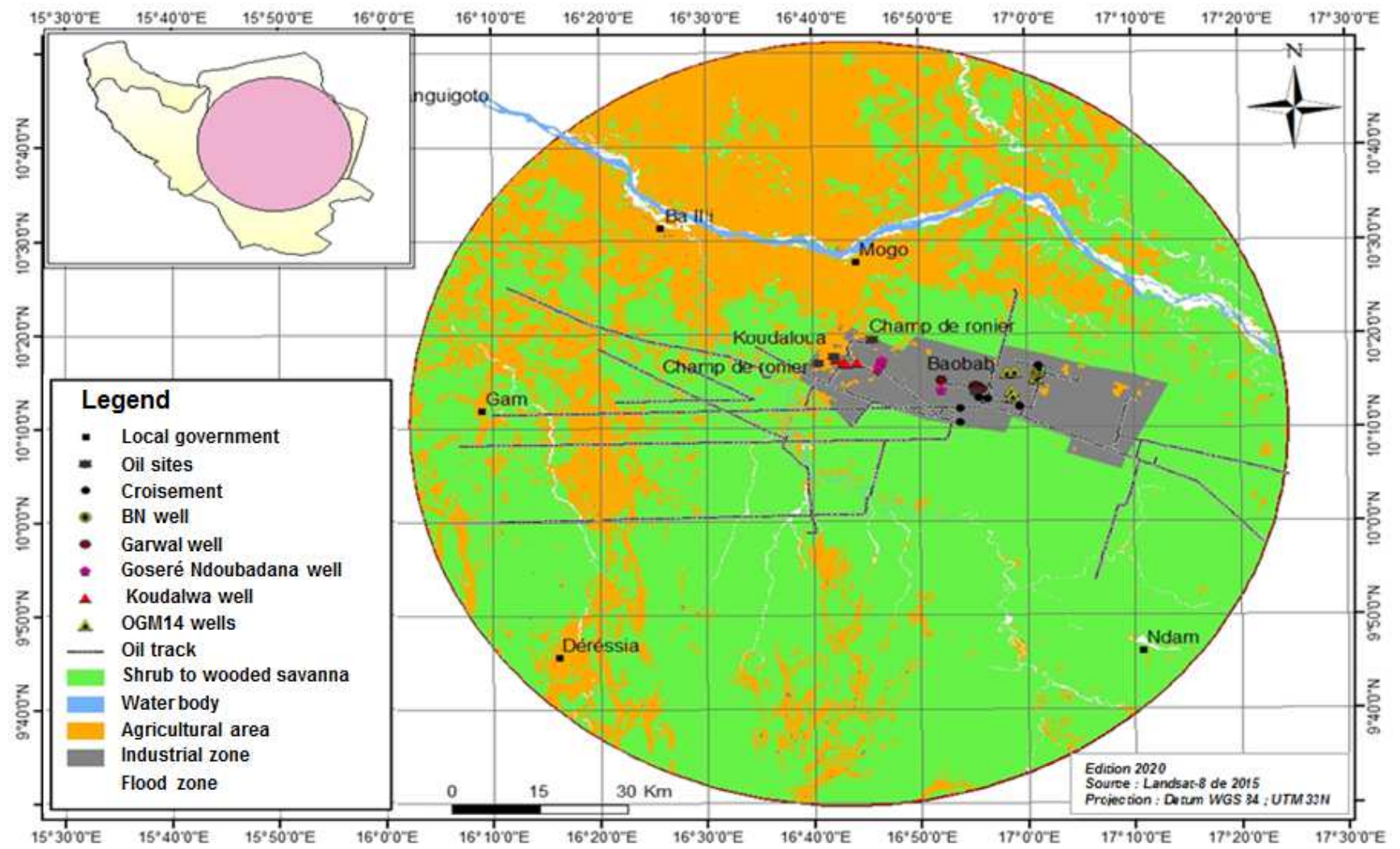

Figure 5. Bongor Basin oil zone in year 2015, illustrating oil facilities, road networks and sampling points.

\subsection{Spatial Mutation of Ecological Parameters in the Bongor Basin}

Statistical analysis of ecological parameters (Table 5) resulting from the difference between entities of 2000 map (Figure 2) and that of 2015 (Figure 3) shows that the evolution of the area of agricultural zone is +590701.01 ha $(+15.15 \%)$; shrub savanna is $-61,862.182$ ha or $-15.75 \%$; herbaceous savanna is $+72,378.74$ ha or $+1.86 \%$; wooded savanna is +3060.6 ha or $+0.07 \%$; floodplain is $-61,731.66$ ha or $-1.59 \%$ and the industrial zone is +3127.45 ha or $+0.08 \%$. This land use dynamic shows a loss of paddy field in 2015 giving way to sand with $+13,628.32$ ha, or $+0.35 \%$ and water body with -79.5 ha or $-0.0007 \%$.

Statistical changes of parameter observed from the superposition of the 2000 and 2015 maps in Bongor basin (Table 6) gives for the natural environment which has remained natural, $-68.93 \%(-2687,299.90$ ha $)$ an area, $15.23 \%$ for natural environment transformed by human activities $(+593,828.75 \mathrm{ha})$ and $53.70 \%$ for regressed natural environment $(+2,093,471.15 \mathrm{ha})$.

Table 5. Spatial mutation of ecological parameters in the Bongor basin.

\begin{tabular}{lll}
\hline Land use classes & Area (ha) & Percentage \\
\hline Agricultural zone & $590,701.01$ & $15.15 \%$ \\
Water body & -79.5 & $-0.0007 \%$ \\
Herbaceous savanna & $72,378.74$ & $1.86 \%$ \\
Wooded savanna & $3,060.6$ & $0.07 \%$ \\
Shrub savanna & $-618,162.18$ & $-15.75 \%$ \\
Sand* & $13,628,32$ & $0.35 \%$ \\
Paddy field* & disappearing & \\
Floodplain & $-61,731.66$ & $-1.59 \%$ \\
Industrial zone & $3,127.45$ & $0.08 \%$ \\
\hline
\end{tabular}

N. B: * ecological parameter disappeared (paddy field) and presence of sand with oil activities and facilities.

Table 6. Ecological parameters after superposition of 2000 and 2015 maps (Bongor basin).

\begin{tabular}{|c|c|c|c|c|}
\hline Change in ecological parameters (Bongor basin) & Area (ha) 2000 & Area (ha) 2015 & Difference between 2015-2000 (ha) & Percentage \\
\hline Natural environment remained natural & $2,694,085.25$ & $6,785.35$ & $-2,687,299.90$ & $-68.93 \%$ \\
\hline Natural environment transformed by human activities & $992,837.60$ & $1,586,666.35$ & $593,828.75$ & $15.23 \%$ \\
\hline Regressed natural environment & $211,482.03$ & $2,304,953.18$ & $2,093,471.15$ & $53.70 \%$ \\
\hline Total & $3,898,404.88$ & $3,898,404.88$ & & \\
\hline
\end{tabular}

\subsection{Spatial Change of Ecological Parameters in the Zone Under Oil Operations}

Statistical analysis of the surface area of the ecological parameters (Table 7) resulting from the difference between entities of the land use map of oil zone of influence from year 2000 prior oil activities (Figure 4) and year 2015 with oil facilities in (Figure 5) shows that the expansion of 
agricultural zone is $+254,501$ ha $(+14.14 \%)$, shrub to tree savanna change is $-334,001$ ha or $-18.90 \%$; industrial zone occupies $+79,328$ ha $(4.49 \%)$. Water body and floodplain have -11 and -24 ha of area respectively.

Statistical analysis of Change in ecological parameters oil zone under operations, observed after superposition of year 2000 and 2015 maps (Table 8) shows change of natural environment remained natural with -334001 ha $(-18.90 \%)$, natural environment transformed by human activities gives an area of 334,035 ha or $18.90 \%$ and the regressed natural environment has an area of -35 ha or $0.00002 \%$.
Table 7. Spatial mutation of ecological parameters of oil zone under operations.

\begin{tabular}{lll}
\hline Land use & Area (ha) & Percentage \\
\hline Agricultural zone & 254,501 & $14.400 \%$ \\
Shrub to wooded savanna & $-334,001$ & $-18.900 \%$ \\
Industrial zone & 79,328 & $4.490 \%$ \\
Water body+ & -11 & $-0.001 \%$ \\
Floodplain+ & -24 & $-0.001 \%$ \\
Urbanized area & 206 & $0.010 \%$ \\
\hline
\end{tabular}

N. B: +the platforms of the oil installations are compacted and the water areas tend to disappear.

Table 8. Ecological parameters after superposition of 2000 and 2015 maps in oil zone.

\begin{tabular}{|c|c|c|c|c|}
\hline Change in ecological parameters in zone under oil operations & Area (ha) 2000 & Area (ha) 2015 & Difference between 2015-2000 (ha) & Percentage \\
\hline Natural environment remained natural & $1,722,538$ & $1,388,537$ & $-334,001$ & $-18.900 \%$ \\
\hline Natural environment transformed by human activities & 44,257 & 378,292 & 334,035 & $18.900 \%$ \\
\hline Regressed natural environment & 376 & 341 & -35 & $0.00002 \%$ \\
\hline Total & $1,767,171$ & $1,767,170$ & & \\
\hline
\end{tabular}

\subsection{Land Cover Rate of Evolution Between 2000 and 2015 (Bongor Basin)}

Rate of change in land use in the Bongor basin between 2000 and 2015 (Table 9) shows that classes representing agricultural zone, herbaceous savanna and wooded savanna are increasing in areas during this period (Figure 6) with $59.50 \%, 1134.34 \%$ and $82.17 \%$ respectively and those declining are, water body, shrub savanna and floodplain (Figure 7) with $40.12 \%, 22,94 \%$ and $31.13 \%$ respectively. It should be noted that industrial zone and silting up observed over the entire basin in 2015 with $3,127.45$ ha or $0.08 \%$ of area and $13,628.32$ ha or $0.35 \%$ respectively, constitute new ecological parameters in the basin and paddy field within this period disappeared.
Table 9. Global rate of spatial change in the Bongor basin between 2000 and 2015 .

\begin{tabular}{lllll}
\hline \multirow{2}{*}{ Land use classes } & Area (ha) & & \multirow{2}{*}{ Tc (\%) } & \multirow{2}{*}{ Tg (\%) } \\
\cline { 2 - 5 } & $\mathbf{2 0 0 0}$ & $\mathbf{2 0 1 5}$ & & \\
\hline Agricultural zone & $992,837.60$ & $1,583,538.61$ & 59.49 & 59.49 \\
Water body & 198.12 & 118.62 & -40.12 & -40.12 \\
Herbaceous savanna & $6,380.68$ & $78,759.42$ & $1,134.34$ & $1,134.34$ \\
Wooded savanna & $3,724.75$ & $6,785.35$ & 82.16 & 82.16 \\
Shrub savanna & $2,694,085.25$ & $2,075,923.07$ & -22.94 & -22.94 \\
Floodplain & $198,255.42$ & $136,523.76$ & -31.13 & -31.13 \\
Paddy field**_2 & $2,923.07$ & & & \\
Sand**2 $^{\text {Industrial zone } * *^{2}}$ & & $13,628.32$ & & \\
\hline
\end{tabular}

N. B: Tc: average annual rate of spatial expansion; Tg: global rate of change. ** _2 ecological parameter disappeared after oil facilities in place.

** 2: ecological parameter appeared after oil facilities in place.

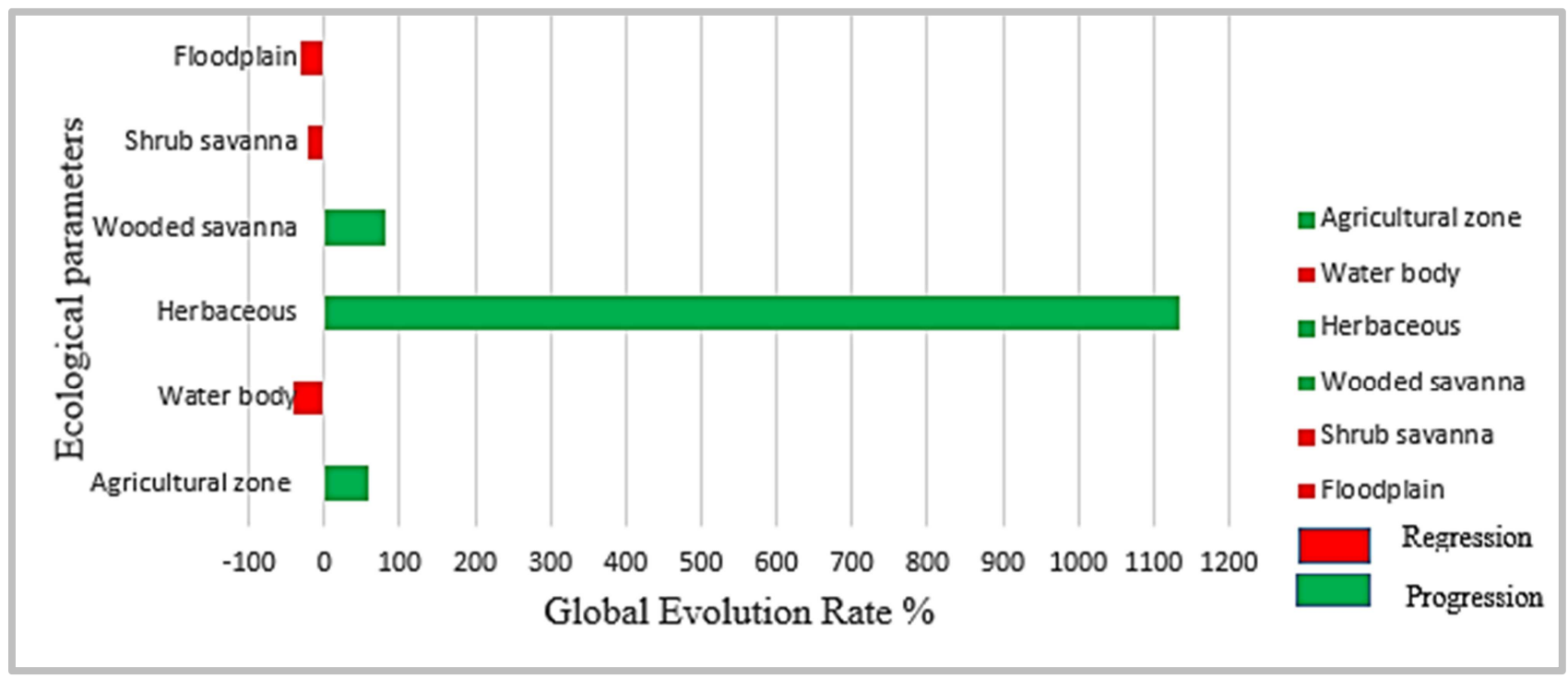

Figure 6. Global rate of spatial change in the Bongor basin between 2000 and 2015. 


\subsection{Land Cover Rate of Evolution Between 2000 and 2015 in Oil Operation Zone}

Land use rate of evolution of ecological parameters in oil operation zone (Table 10) shows that these ecological parameters of land use have undergone significant changes. The ecological parameters (Figure 7): agricultural zone, industrial zone and urbanized zone have very high global change rates with $578.10 \%, 63462.4 \%$ and $188.99 \%$ respectively (Table 10). Other three (3) ecological parameters: floodplain, water body and shrub to wooded savanna are declining with $-19.39 \%,-6.54 \%$ and $-11.53 \%$ respectively (Table 10).
Table 10. Global rate of change in space between 2000 and 2015 of the zone put into operation.

\begin{tabular}{|c|c|c|c|c|}
\hline \multirow{2}{*}{ Land use classes } & \multicolumn{2}{|l|}{ Area (ha) } & \multirow{2}{*}{$\begin{array}{l}\text { Tc } \\
(\%)\end{array}$} & \multirow{2}{*}{$\operatorname{Tg}(\%)$} \\
\hline & 2000 & 2015 & & \\
\hline Agricultural zone & 44,023 & 298,524 & 12.76 & 578.11 \\
\hline Shrub to wooded savanna & $1,722,538$ & $1,388,537$ & -1.43 & -19.39 \\
\hline Industrial zone & 125 & 79,453 & 43.03 & $63,462.40$ \\
\hline Water body & 168 & 157 & -0.45 & -6.54 \\
\hline Floodplain & 208 & 184 & -0.81 & -11.53 \\
\hline Urbanized area & 109 & 315 & 7.07 & 188.99 \\
\hline
\end{tabular}

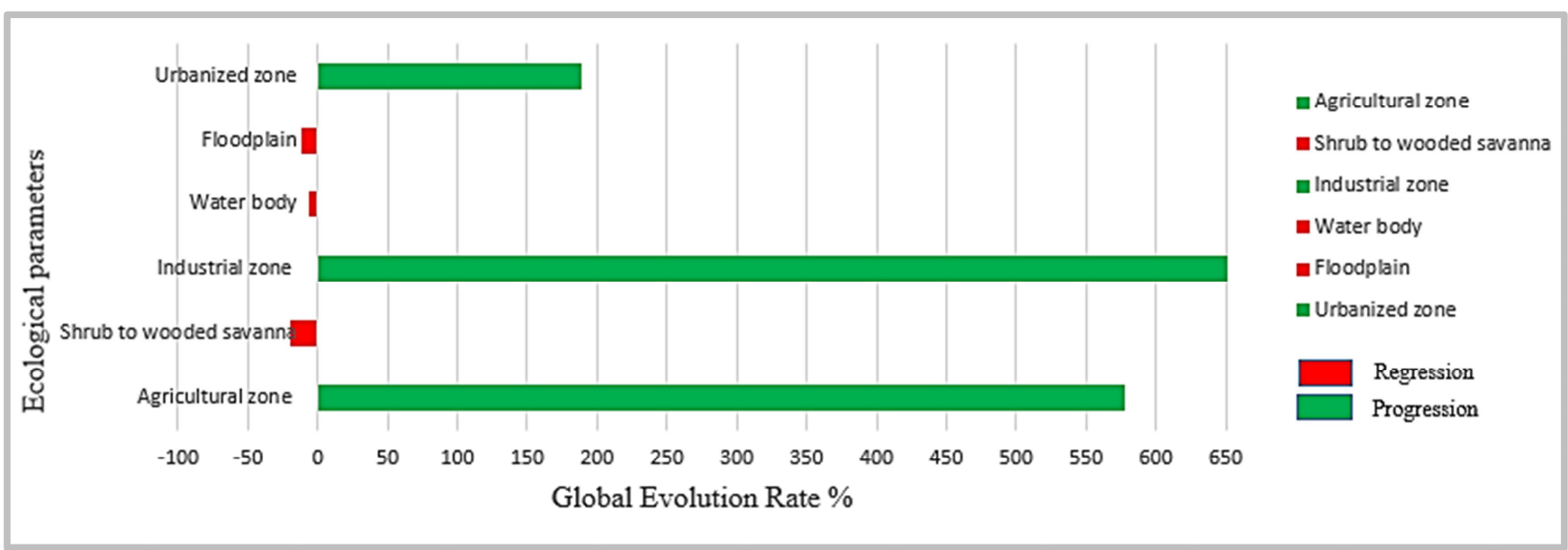

Figure 7. Global rate of spatial evolution of the oil exploitation zone of influence in the Bongor basin between 2000 and 2015.

\section{Discussion}

Dynamics of Land Use Between 2000 and 2015

Industrial establishment and oil activities in 2015 show remarkable changes in the ecological parameters of land use in entire Bongor basin (Tables 5 and 6). Agricultural zone revealed an increased by $15.15 \%$ and wooded savanna as well by $0.07 \%$. At the same time, shrub savanna is in decline by $-15.75 \%$. There is a decrease in water body and floodplain with respectively $0.007 \%$ and $1.59 \%$. From 2015 period, paddy field loss has been witnessed with tremendous shift in land giving way to the appearance of sand occupying 13,628.32 ha of the total area. These observations and analyzes are in agreement with the trend observed in the Cuyabeno region in which oil facilities contributed to deforestation or forest degradation [30].

Spatio-temporal changes that occur between two periods 2000 and 2015 in Bongor basin (Figure 2 and Figure 3) illustrate negative evolution of shrub savanna with an overall change rate $(\mathrm{Tg})$ of $-31,13 \%$ and an average annual spatial expansion rate $(\mathrm{Tc})$ of $-2.48 \%$ (Table 9). These regressive changes are attributed to deforestation for the benefit of oil facilities and infrastructures in place. These regressions phenomenon is also observed in project area of Amazon where rate of deforestation in the Ecuadorian Amazon region evaluated to be $4 \%$, which corresponds to $3000 \mathrm{~km} /$ year of forest lost [22]. Moreover, agricultural areas are recording increase of $3.11 \%$ in annual average rate of spatial expansion following the development of new farming fields due to its economic added value to farmers with demographic expansion around oil companies.

It has also been observed that in oil zone under operation named 'zone of influence', industrial zone and agricultural zone cover respectively up to $4.49 \%$ and $14.40 \%$ of the total area and gradual increase in urbanized areas of $0.01 \%$. These parameters illustrate annual growth rate between 2000 and 2015 respectively to be $12.76 \%$ for agricultural zone, $43.03 \%$ for industrial area and $7.07 \%$ for urbanized zone (Table 10). Consequently, influence of petroleum facilities and activities has impact on initial natural environment with $18.90 \%$ of rate (Table 8).

Shrub to wooded savanna, water body and floodplain are in considerable regression respectively by $-18.90 \%,-0.001 \%$ and $-0.001 \%$ (Table 7 ), and thus showing annual regression rate of $-1.43 \%$ for shrub to wooded savanna, $-0.45 \%$ for water body and $-0.81 \%$ for floodplain (Table 10). Consequently, dynamic analysis of land use in oil zone of influence and facilities shows strong degraded quality of environment due to destruction of vegetation, wetlands lost to installations and petroleum equipment. Despite this small scale, impacts are significant due to roads opening and clearings [15]. It has also been proved that oil and gas exploration in the Haynesville Shale area had disturbed forest and agricultural lands [29]. 


\section{Analysis of Petroleum Activities Impact on Land in Oil Operating Area}

Oil facilities establishment and various oil exploitation activities in this basin, have caused shrub savanna to regress with an average annual spatial expansion rate of $-1.73 \%$, an overall rate of change of $-22.94 \%$ (Table 9) and a spatial mutation between 2000 and 2015 of $15.75 \%$ (Table 5). This same ecological parameter in oil zone under operations is also declining with an average annual spatial expansion rate of $-1.43 \%$, an overall rate of change of $-19.39 \%$ and a spatial mutation of $18.90 \%$ (Table 7 ). It is also observed that natural environment transformed by human activities (Table 8) allows the progression of the sparse forest. From field observations, this is due to intensification of exploration activities, tracing of seismic lines, construction of exploitation structures and the establishment of quarries which involves destruction of trees during the process. This phenomenon of regression in vegetation and land cover has also been observed in the farming regions in North-West Siberia [25]. This regression is justified by the obvious direct impacts of buildings, roads and heavy machinery vehicle tracks associated with industrial oil activities [25]. Similar case of Tundra vegetation reduction in Bovanenkovo oil and gas field was observed using multi-year Landsat and Satellite scenes, it is believed that negative impacts of oil development and gas in Northwest Siberia have raised concerns for the ecological environment in these areas [13, $14,21]$. Research work on the environmental management of offshore oil exploitation in Niger Delta also shows that oil exploration, field preparation, production and other activities require creation of access roads through mangrove forests, for the passage of men and equipment; these field preparations include opening of roads, settling of base camps, drilling sites and oil pipelines: these activities destroy a considerable amount of vegetation and that mangroves located at one side and the other of roads that are isolated from natural flow of water end up dying [12]. Floodplain and water body over the whole Bongor basin are in regression with average annual change of $-2.48 \%$ and -3.41 , and overall change of $-31.137 \%$ and $-40,12$ respectively (Table 9). The resulting spatial mutation also gives $1.59 \%$ for floodplain and $0.0006957 \%$ for water body (Table 5). It is also witnessed in year 2015, a loss of paddy field due to silting up (Table 5) of the area. Natural environment which has remained natural has declined by $-68.93 \%$ (Table 6). Floodplain and water body regression and loss of paddy field, are in one way or another associated to various works and oil activities in this area; construction of well platforms, oil production facilities and gathering networks, electrical and road networks isolate certain parts of land from others which, before hydrocarbons operations, are supplied by natural flow of surface waters. According to findings and fields observations, this could be explained by the intensification of works requiring a huge amount of soil to compact alleys, wells and other facilities platforms; by doing these works, good number of quarries are dug in many places and are widely open to absorb largest part of surface water which initially spread throughout the bush and fed paddy fields.

The more or less stable spatial change in the operational area can be explained by the permanent occupation or establishment of oil infrastructure. A similar study at Ilorin and its surroundings in Kwara State, Nigeria, confirms these facts [31]. The phenomenon of regression of water and floodplain as well as silting were also notified at the beginning of oil and gas exploration and exploitation in Niger Delta; and other environmental problems associated with oil activities are oil spills, gas flaring, pipeline, depletion of forest resources, coastal erosion and changes in land use/vegetation [1]. Analysis on land use change in Port Harcourt city in Nigeria also showed that water bodies decreased by $18 \%$ from 1996 to 2007 and marshes by $16 \%$ over the same period, and it was concluded that this could be the result of various oil activities in the environment [20]. Other studies conducted in the Amazon oil exploitation area of Cuyabeno, Ecuador, have also shown that oil infrastructure interfere with waters flowing mechanisms by disrupting natural flows [30]. The regression of shrub and wooded savanna can also be the cause of silting up. Similar case of silting up of areas was described in Niger Delta oil operations sites, that this phenomenon is associated to sudden and massive mortality of mangrove trees causing sediment erosion [8].

Agricultural area has increase with an average annual change of $3.112 \%$, an overall change of $59.496 \%$ (Table 9) and a spatial mutation of $15.15 \%$ in the Bongor Basin (Table 5 ). And in the area of oil operation, there is a very large overall rate of change of $578.11 \%$, an average annual change rate $12.760 \%$ (Table 10 ) and a spatial mutation of $14.40 \%$ (Table 7). According to surveys and field observations, the growth in agricultural area may be associated with land use by oil companies with an increase of industrial zone of $4.49 \%$ of the total area under oil operation (Table 7) and the increasing demand for food which leads to an increase in agricultural production as well as an increase in agricultural land use [26].

In addition to this, oil operation and activities attract more visitors seeking job opportunities and who end up creating new homes, and investing in agriculture to meet food needs, resulting in increasing of urbanized areas of $0.01 \%$ and an overall change rate of $188.990 \%$ in area of oil operation. This analysis is in line with the one observed in Port Harcourt where increase in urban space due to the economic pressure is also associated with oil activities impacting the use of residential land or urbanized area $[20,26]$.

\section{Conclusion}

Remote sensing is an important tool for assessing impacts of various activities and the complexity of oil facilities in the Bongor basin. Ecological parameters during the 2000s period before oil development and the period when oil activities were intensified in 2015, have highlighted impacts associated with oil installations and activities in the Bongor Basin. 
Statistics from dynamic land use analyses in Bongor Basin revealed environmental negative changes such as; destruction of vegetation, disappearance of wetlands for oil industrial expansion. These changes in ecological parameters are quantified by regressive rate of evolution of shrub savannah with the overall rate of change of $-31.13 \%$ and average annual rate of spatial expansion of $-2.48 \%$. In of oil exploitation area, the increasing parameters are, industrial zone, agricultural area and urbanized areas representing $4.49 \%, 14.40 \%$ and $0.01 \%$ respectively with corresponding annual growth rate between 2000 and 2015 of $12.76 \%$, $43.03 \%$ and $7.07 \%$.

Globally, natural environment remained natural in this basin declined by $-68.93 \%$, the natural environment transformed by human activities increased by $+15.23 \%$ and regressed natural environment increase by $+53.70 \%$. And with regard to the oil operation area, the natural environment remained natural by $-18.90 \%$, the natural environment transformed by human activities by increasing $18.90 \%$.

Oil prospection to production processes, road constructions, electrical networks, pipeline constructions, quarries and well platforms and other related field activities have generated at various level as shown in this study. Changes in ecological parameters of land use, vegetation cover, disappearance of paddy field, soil erosion with sand accumulation impacting on natural flow and decrease in surface and underground water levels have also been observed. Other reasons related to these ecological (Urbanized area and agricultural zone) changes associated to oil activities, is the increase in population and human activities in oil operating zone.

\section{Conflict of Interest Statement}

Authors have not declared any conflict of interests.

\section{Acknowledgements}

We acknowledge Chadian Ministry of Energy and Petroleum for making available archives as well as authorizing access for data collection and field research in petroleum industrial zones of Bongor basin. We are also indebted to Higher National Petroleum Institute of Mao in Chad, for its support and determination to see this research work come to success. Our gratitude to Prof. EWODO MBOUDOU Guillaume for his tremendous contributions and who day and night followed this research work step by step to this point.

\section{References}

[1] Abbas, I. I. (2012). An assessment of land use/cover changes in a section of Niger Delta, Nigeria. Frontiers in Science, 2 (6), 137_143.

[2] ANONYMOUS 1, 2017. Archives of the Ministry of Energy and Petroleum 2015-2018, Environmental Impact Study,
Rônier Project, Socioeconomic Report and Compensation and Resettlement Plan Provisional Document, N'Djamena. ISM CONSULT.

[3] ANONYMOUS 2, 2017. Archives of the Ministry of Energy and Petroleum 2015-2018, Madiago Basin Exploration Project, Environmental Impact Study conducted by ISM (Chad) For CNPC International (Chad) Co., Ltd. Volume 1.

[4] ANONYME 3, 2017 Archives of the Ministry of Energy and Petroleum 2015-2018. Ronier and Mimosa Oilfield Development Program in Bongor Basin. CNPC International (Chad) Ltd.

[5] Atlas, 2013 Sahara observatory and Sahel Atlas of Vegetation Maps, Chad.

[6] Boettinger, J. L., R. D. Ramsey, J. M. Bodily, N. J. Cole, S. Kienast-Brown, S. J. Nield, A. M. Saunders and A. K. Stum 2008 Landsat Spectral Data for Digital Soil Mapping.

[7] Gao, B.-C., (1996). NDWI, a normalized difference water index for remote sensing of vegetation liquid water from space. Remote sensing of environment, 58 (3): p. 257-266.

[8] Garrity, S., Levings, S., Burns, K. A., 1994. The Galeta oil spill I, long term effects on the structure of the mangrove fringe. Estuarine, Coastal and Shelf Science 38: 327-348.

[9] Geerken R., Ilaiwi M., 2004, Assessment of rangeland degradation and development of a strategy for rehabilitation, Remote sensing of environment, ${ }^{\circ} 90$, pp 490-504.

[10] Hallberg, G. R., Hoyer, B. E. and Rango, A. 1973"Application of ERTS-1 Imagery to Flood Inondation Mappins", Proceedings of the Symposium on Significant Results Obtained from the Earth Resoursces Technology Satellite-1, NASA, SP-327, pp. 745-753.

[11] Harker, G. R. 1974 "The Delineation of Flood Plains Using Automatically Processed Multispectral Data", Technical Report RSC-60 Texas A\&M University, Remote Sensing Center, College Station, Texas, August.

[12] Kloff Sandra -Wicks Clive (2005) Environmental management of offshore oil and oil shipping.

[13] Kumpula T, Forbes B C, Stammler F and Meschtyb N (2012) Dynamics of a coupled system: multi-resolution remote sensing in assessing social-ecological responses during 25 years of gas field development in Arctic Russia Remote Sensing 4 1046-68.

[14] Kumpula T et al. (2011) Land use and land cover change in Arctic Russia: ecological and social implications of industrial development Glob. Environ. Change 21 550-62.

[15] La Rovere, E. L. (1995) Environmental policy and energy planning, PPE/COPPE/UFRJ, Rio de Janeiro.

[16] Lambin, E. F., Turner, B. L., Geist, H. J., Agbola, S. B., Angelsen, A., Bruce, J. W., et al. (2001). The causes of landuse and land-cover change: Moving beyond the myths. Global Environmental Change, 11 (2), 261-269.

[17] Loveland T. R., \& Acevedo W. (2006) Land cover change in the Eastern United States, US Geological survey. https://landcovertrends.usgs.gov/east/regionalSummary.html.

[18] Lu D., Mausel P., Brondizio E. \& Moran E., 2003: Change detection, techniques. International Journal of remote sensing, 25 (12): 23652407. 
[19] Mama V. J. -Oloukoi J., 2003: Evaluation of the accuracy of analogue treatments of satellite images in the study of the dynamics of land use. Remote sensing, 3 (5): 429-441.

[20] Mmom, P. C., \& Fred-Nwagwu, F. W. (2013). Analysis of landuse and landcover change around the city of Port Harcourt, Nigeria. Global Advanced Research Journal of Geography and Regional Planning, 2 (5), 076_086.

[21] Moskalenko NG (2013) Impact of climate warming on vegetation cover and permafrost in West Siberia northern Taiga Nat. Sci. 5 144-8.

[22] Myers, N. (1984). The primary Source: Tropical Forests and Our Future. New York: Norton.

[23] Oloukoi, J., Vincent Joseph MAMA and Fulbert Bernadin AGBO, 2006, Modelling of land use dynamics in the Benign Hills Department, Remote Sensing, 2006, Vol. 6, No. 4, p. 305-323.

[24] PANA, 2010 and 2013. National Climate Change Adaptation Programme (PANA-Chad), UNDP/UNFCCC.

[25] Qin Yu, Howard E Epstein, Ryan Engstrom, Nikolay Shiklomanov (2015) Land cover and land use changes in the oil and gas regions of Northwestern Siberia under changing climatic conditions.
[26] Saheed Matemilola, Oludare Hakeem Adedeji and Evidence Chinedu Enoguanbhor (2017) Land Use/Land Cover Change in Petroleum-Producing Regions of Nigeria DOI: 10.1016/B978-0-12-809399-3.00017-3.

[27] Soro, G., E. K. Ahoussi, E. K. Kouadio, T. D. Soro, S. Oulare, M. B. Saley, N. Soro and J. Biemi, Contribution of remote sensing for spatial-temporal mapping of land use dynamics evolution in the Lakes region (Central Ivory Cost), Africa SCIENCE, 201410 (3) p: 146-160.

[28] Tucker, C. J. Red and photographic infrared linear combinations for monitoring vegetation. Remote Sens. Environ. 1979, 8, 127-150.

[29] Unger, Daniel; Hung, I-Kuai; Farrish, Kenneth W.; and Dans, Darinda, (2015) "Quantifying Land Cover Change Due to Petroleum Exploration and Production in the Haynesville Shale Region Using Remote Sensing".

[30] Yves Barthélemy (1998). Deforestation in Amazon oil exploitation zone: causes, balance sheet, outlook Cuyabeno case (equator), D.E.S.S "management of Agro-Sylvo-Pastoral systems in tropical zones".

[31] Zubair A. O, (2006). "Change Detection in Land Use and land Cover using Remote Sensing data and GIS: A case study of Ilorin and its environs in Kwara State". 